\title{
THE EFFECTS OF LEGISLATION ON CORPORATE SOCIAL RESPONSIBILITY IN THE MINERALS AND MINES SECTOR OF NIGERIA
}

\author{
Adedoyin Akinsulore*
}

\begin{abstract}
This paper examines the effect of legislation on the corporate social responsibility in the minerals and mines sector of the Nigerian economy. Observing that the extractive industry sector in the country is populated by enclave industries that give little priority to CSR, the paper analyses the Nigerian Minerals and Mines Act, 2007. The Act obligates contracting a Community Development Agreement (CDA) between the mineral title holder and the community where the mining company is to operate. Linking CSR and the CDA through the stakeholder theory, the paper observes that corporate actors in the solid minerals sector of the country can no longer deprioritise CSR in their corporate planning as hitherto. It concludes that the effect of this law is to empower the community as an important stakeholder thereby validating the stakeholder thesis herein espoused.
\end{abstract}

Keywords: Corporate social responsibility (CSR), minerals, mines, agreement, human rights.

doi: http://dx.doi.org/10.4314/jsdlp.v6i2.5

\section{INTRODUCTION}

This paper examines the effect of legislated Corporate Social Responsibility in the minerals and mines sector of the Nigerian economy. Observing that the extractive industry sector in Nigeria is populated by enclave industries that give little priority to CSR, the paper analyses the Nigerian Minerals and Mines Act, 2007. The Act obligates contracting a Community Development Agreement (CDA) between the mineral title holder and the community where the mining company is to operate. The paper examines the theoretical underpinnings, which inform companies to engage in CSR and the need to re-

* Department of Public Law, Obafemi Awolowo University, Ile-Ife, Nigeria e-mail: adedoyinakinsulore@gmail.com or adakinsulore@oauife.edu.ng 
engage the ideology of the firm to the importance of the community as an important stakeholder through contractual agreements such as the CDA. The paper analyses the corporate practice of the CSR of Dangote Cement, a local conglomerate in the mineral and mine sector of the country, in order to ascertain the level of its compliance with the law and observed modern practice on corporate social responsibility.

\section{COMMUNITY DEVELOPMENT AGREEMENT (CDA) ${ }^{1}$ AND THE NIGERIAN LAW}

Community Development Agreements (CDA) are agreements reached between host communities and mining companies to provide some social facilities to aid in the economic, social and general development of their host community. The NMMA 2007 provides that prior to the commencement of any development activity within the lease area, the lessee shall enter into a binding agreement with the host community where the operations are to be conducted or any other such agreement that would ensure the transfer of social and economic benefit to the community. This provision is applicable to holders of Mining Lease, Small-Scale Mining Lease or Quarry Lease. It is a condition precedent that must be fulfilled by any of these mineral title-holders before they could commence development activity on the mining site.

The Minerals and Mining Act of 2007 mandates mining companies to consultatively reach Community Development Agreements (CDAs) with their prospective host community towards the provision of social and economic benefits that will enhance the sustainability of the host community. ${ }^{2}$ This provision is novel as it is absent in the previous mining Acts. ${ }^{3}$ Furthermore, a detailed look at the Petroleum Act of 1969, finds a provision of this nature absent.

Perhaps the inclusion of this important provision in the NMMA 2007 is informed by the experience of the people of the Niger Delta region of the country as oil is being exploited by the Multi-National Oil Companies (MOCs). This experience is characterised by pollution of the riverine areas of the Niger Delta as a result of oil spillage; destruction of livelihood of the members of the host community as majority of them are fishermen; disempowerment

1 Section 116 of the NMMA 2007.

2 Ruth Tene Natsa, "Enforcing CDA Will Enhance Development in Host Mining Communities" The Leadership Newspapers (20 November 2014).

3 Minerals and Mining Act, Cap M12 L.F.N 2004. 
and dislocation of people many of who had no other occupation or means of survival. ${ }^{4}$ No doubt the oil industries located within this region have contributed immensely to the growth and development of the country but unsustainable oil exploration activities has rendered the Niger Delta region one of the five most severely petroleum damaged ecosystems in the world. This has affected the livelihood of the indigenous people who depend on the ecosystem services for survival. The result has been astounding poverty in the midst of plenty and displacement of the people. ${ }^{5}$ Naturally, this disenfranchisement has led to the notorious militant struggle in the Niger Delta and the consequent disruption of oil production in the region. ${ }^{6}$

While the NMMA 2007 did not explicitly define the term Community Development Agreement (CDA), what can be interpreted from the Act is that it entails the transfer of "social" and "economic" benefits from the lessee mineral title holder to the host community. It could be deduced, therefore, that the Act presumes that the mineral title holder has or is endowed with reasonable amount of social and economic benefits which the Act now obliges the mineral title holder to share with the community. We can further deduce that the Act presumes the community lacks or is likely to lack certain social and economic benefits. These social and economic benefits include educational scholarship, apprenticeship, technical training and employment opportunities for indigenes of the communities; ${ }^{7}$ financial and other forms of contributory support for infrastructure development and maintenance ${ }^{8}$ assistance with the creation, development and support to small-scale and micro enterprises; ${ }^{9}$ as well as agricultural product marketing. ${ }^{10}$

Where the parties properly enter into this agreement, it shall be enforceable at law and shall be subject to review, every five years. ${ }^{11}$ However,

4 See Kadafa, Adati Ayuba, "Environmental Impacts of Oil Exploration and Exploitation in the Niger Delta of Nigeria" (2012) 12(3) Global Journal of Science Frontier Research Environment \& Earth Sciences; See also Tarila Marclint Ebiede, "Conflict Drivers: Environmental Degradation and Corruption in the Niger Delta Region"(2011) 1 (1) African Conflict and Peacebuilding Review 139; See also Oyeniyi Okunoye, "Alterity, Marginality and the National Question in the Poetry of the Niger Delta" (2008) 48(191) Cahiers d'Études Africaines 413.

5 Kadafa (n 4).

6 See Tarila Marclint Ebiede (n 4).

7 Section 116 (3) (a.

8 Section 116 (3) (b).

9 Section 116(3)(c).

10 Section $116(3)(d)$.

11 Section 116 (5) 
where for one reason or another the host communities and the lessee mineral title holder fail to conclude on the terms of the agreement after several attempts by the time the mineral title holder is ready to commence development work at the mine site, such matter shall be referred to the Minister for resolution. ${ }^{12}$

The objective for the legislative imposition of a CDA on the mineral title holder is to allow for an interface between the host communities and the mining companies for shared commitment to the mining enterprise between the host communities and the mineral title holders. ${ }^{13}$ This is also to avoid a disconnect between the host community and reality of an invasive activity brought on their community by the mining industry as it allows for mutual dialogue between the parties before the mining activities commences. The $\mathrm{CDA}$, in fact, is a pre-licence requirement but often time many communities in Nigeria are ignorant of this requirement in the NMMA, 2007. Consequently, the mining companies exploit this ignorance to their advantage, denying host communities this statutory right. ${ }^{14}$

While the Minerals and Mining Regulations expect a mineral title holder to identify the community leaders known and recognised by the people and who exercise a reasonable degree of control over them, it does not provide for oversight by the supervising ministry. ${ }^{15}$ These weaknesses in the Mining legislation have been exploited by prominent indigenous mining companies ${ }^{16}$ to commence mining activity without negotiating a proper CDA with host communities. Alternatively, they hand-pick a few community leaders who are given pecuniary inducements without the knowledge of their people. ${ }^{17}$ The preferred position as expressed by most host communities is that the CDAs should be negotiated with the recognised local community authority, along with their cabinet members/elders, as well as the representatives of the men, women and youth groups in the communities.

12 Section 116 (3)

13 Section 117

14 Natsa (n 2)

15 ibid. An assessment report on extractive host companies in Nigeria by global rights revealed that most mining companies do not have formal CDAs with host communities even in instances where such companies had been operating in the communities for years. See the report of Global Rights, "Protecting Host Community Rights: An Assessment Report on Extractive Host Communities in Nigeria" < www.globalrights. org/Library/Natural\%20Resources\%20and\%20human\%20rights/Assessing_ Community_Rights_Report.pdf> accessed 2/11/2015.

16 Dangote Cement in particular.

17 See the problem Dangote Cement has been having with the youth of Ibese, Ogun State, Nigeria, over its refusal to negotiate a CDA with the community while mining of limestone has commenced. 
With governments, companies, and communities seeking to develop a sustainable and mutually beneficial relationship, CDAs can provide a means of strengthening and advancing this relationship. ${ }^{18} \mathrm{CDA}$ serves as a tool for building trust, community relations and social economic development within the host community where mining takes place. The concept of "social licence" to operate is an amalgam of several sociologically based features. It finds expression in the fact that social licence cannot be paid for but can only be earned or built over a period of social relation.

\section{COMMUNITY DEVELOPMENT AGREEMENT AND CORPORATE SOCIAL RESPONSIBILITY IN THE NIGERIAN MINING INDUSTRY}

In achieving its economic aim, activities of industries engaged in the exploitation of solid minerals directly impacts on the community where such solid mineral is mined. The peoples of the community may not have any administrative or policy say in the way the mining company is run. Indubitably, dissatisfaction with the activities of the mining company by the host community would, in most cases, disrupt the proper functioning of such company in the achievement of its economic and financial targets. Several theories address the relationship between the responsibilities of mining companies to the community where they operate. Of these, the stakeholder theory is the meeting point between Corporate Social Responsibility (CSR) and Community Development Agreement (CDA). ${ }^{19}$

18 Ghulam Dastgir Khan, "Community Development Agreement" (2014) National and Regional Resource Corridors Program Secretariat, Ministry of Mines Afghanistan < mom.gov.af/content/files/cda_pres> accessed 15 April 2015.

19 The argument as to whether the stakeholder of a company should be restricted to shareholder or be expanded to include the community and environment still endures. Milton Friedman famously asserted that the sole business of business is business. Others have argued that ignoring the reality of other stakeholders such as employees, customers, the host community, the environment, etc., is recipe for a dysfunctional articulation of a firm's responsibility on its way to achieving its economic aim. See Milton Friedman, Capitalism and Freedom (40th anniversary edition, University of Chicago Press, Chicago, 2002); See also Friedrich Hayek, "The Corporation in a Democratic Society: In whose interest alight it and will it be run?" in M. Ashen and G. Bach (eds.), Management and Corporation (McGraw-Hill, 1985) 100; Nojeem Amodu, "Theoretical Underpinnings of CSR; Victim of Ideological Clashes" (2014) 6(3) Journal of Corporate Governance 1214, 1225; See Laurie J. Mullins, Management and Organisational Behaviour (Prentice, 2002); M.A Lateef, "CSR: Between Moral Obligation and Legal Regulation" (2013) IFJR Part 2 (July-December). 
While the primacy of the shareholder as an important stakeholder in the company is not in doubt, the objective reality of the modern business environment is that a restrictive interpretation of the stakeholder in a business is theoretically and practically unrealistic. The question on the linkage between CSR and CDA is better understood with a clarification of what CSR entails.

Companies, businesses and society are more connected and interactive than ever before. Corporations are more aware of their role towards the society. They are expected to be responsible bodies with a sense of duty towards common resources and the environment. There is a growing realisation that they, as an integral part of this society themselves, can contribute to its development. ${ }^{20}$ Thus CSR should not be defined to denote corporate charity or the idea of giving back to the society or corporate action done beyond the legal requirements, ${ }^{21}$ but should be employed as "the obligation of business and society to take proper legal, moral, ethical and philanthropic actions that will protect and improve the welfare of both society and business as a whole, all of which must be accomplished within the economic structures and capabilities of the parties involved." 22

CSR is in reality the alignment of business operations with social values. It takes into account the interests of stakeholders in the company's business policies and actions. It focuses on social, environmental and financial success of a company with the aim to achieve social development while achieving business success. Viewed from another angle, CSR can be seen as an obligation (social or legal) which concerns the actual and possible social impact of the activities of corporation in question, whether or not these activities are intended or do in fact promote profitability of the particular corporation. ${ }^{23}$

In the global community today, particularly developing countries, it is realised that individual and government efforts have not been enough to meet the challenges of development at the pace it is actually needed. Fortunately,

20 Amita V. Joseph, "Successful Examples of CSR" (2009) 44(3) Indian Journal of Industrial Relation, p. 402.

21 Nojeem Amodu, "Theoretical Underpinnings of CSR: Victim of Ideological Clashes" (2014) 6(3) Journal of Corporate Governance, p. 1217.

22 Gabriel Eweje, "Multinational Oil Companies" CSR initiatives in Nigeria: The Skepticism of Stakeholders in Host Communities' (2007) 49 (5/6) Managerial Law 218-35. Citing Ojala, M "Funding Socially Responsible Companies" 17(5) Database 86-89.

23 Tom Campbell, "The Normative Grounding of CSR: A Human Rights Approach", in Doreen McBarnet, Aurora Voiculescu and Tom Campbell (eds), The New Corporate Accountability: Corporate Social Responsibility and the Law (Cambridge University Press 2007) 529-64, 541-542. 
with the acceptance of CSR as a global corporate culture, more companies now perform in non-financial arenas such as human rights, business ethics, environmental policies, community development and corporate governance. ${ }^{24}$ The focus of corporations on these new areas is not altruistic by itself. In reality, the social and environmental performance of a company are considered side by side with financial performance and companies are being held accountable for their actions and their impacts. ${ }^{25}$

Some few international conglomerate ${ }^{26}$ have realised the advantage of linking corporate strategy with CSR by instituting comprehensive programmes for its not-for-profit-initiatives within communities providing health services, education and other tangible benefits to the targeted community. But more importantly, this initiative is targeted towards developing or building selfreliant communities and working towards sustainable livelihood. Thus CSR has moved from being a public relations tool or a feel-good factor to a key parameter to keep companies open and transparent. It no longer stands in isolation but has become a part of good corporate governance policies. ${ }^{27}$

For the new generation of corporate leaders, optimisation of profits is key rather than the maximisation of profit. There is, therefore, a theoretical shift from accountability to shareholders to accountability to stakeholders. Furthermore, there is a growing perspective shaping the principles and practice of corporate social responsibility. This is a right-based perspective which stresses that consumers, employees, affected communities and shareholders have a right to know about corporations and their business. ${ }^{28}$ While it is granted that corporations are private initiatives, they are becoming public institutions whose survival depends on the cooperation of other stakeholders. Accountability, transparency, social and environmental investment are the tenets keenly espoused by this perspective as the key aspects of CSR. ${ }^{29}$

CSR has gone beyond the traditional paradigm, which represents it as the extension of a financial input for a humanitarian cause. Ethical values are intertwined in the contemporary interpretation of CSR. Thus, where a company undertakes activities aimed at communities (be they philanthropic, social investment or commercial initiatives) but does not comply with ethical business practice it cannot be termed socially responsible. Corporations have

24 Amita (n 20) 403.

25 ibid.

26 Such as Tata, Mahindra \& Mahindra in India.

27 Amita (n 20) 404.

28 ibid.

29 ibid. 
been viewed to act in a socially responsible way if:

[T]hey must not knowingly do anything that could harm their stakeholders - notably their investors, employees, customers, suppliers or the local community within which they operate. Secondly, if corporations do cause harm to their stakeholders, they must then rectify it whenever the harm is discovered and brought to their attention. ${ }^{30}$

Looking at a country like China, the concept of CSR has assumed a new dimension as a recent tragic event in the mine sector has drawn attention to the neglect of safety standards by coal mine owners in favour of economic gain. ${ }^{31}$ This has changed in recent times as a function of direct government legislative involvement to entrench CSR into the corporate culture of Chinese business and also the external influence of foreign multinational companies (particularly from Europe and the USA) who require their Chinese partners to take responsibility for the social and environmental impact of their business activities. $^{32}$

Even though there is a lack of enforcement of CSR standard set in Chinese law $^{33}$ it has been suggested that government should improve the awareness of its officials, especially at the local government level, to the need for enforcement of statutory provision for the entrenchment of CSR. ${ }^{34}$ Furthermore, workers should be made more aware of their own rights through making CSR standards, enforcement procedure and relevant remedies widely known among workers. ${ }^{35}$

However, the concept of CSR is gaining ground very slowly in the extractive industry. This is perhaps because the relationship between the resource-rich countries and the extractive industry makes the extractive sector an enclave

30 John L. Campbell, "Why would Corporations Behave in Socially Responsible Ways? An Institutional Theory of Corporate Social Responsibility" (2000) 32 (3) The Academy of Management Review, 946, 951.

31 The death of 92 people in a coalmine blast that occurred in 2009 has shown that coal mines are dangerous in China and accidents frequently occur throughout the provinces. See Ying Chen, "Corporate Social Responsibility from The Chinese Perspective” (2011) 21 Ind. Int'l \& Comp. L. Rev. 419.

32 Ying Chen (n 31), pp. 419, 420.

33 For example, as embedded in laws such as the Labour Law of The People's Republic of China (1995); The Law of the People's Republic of China in Protection of Consumer Rights and Interests (1994); The Environmental Protection Law of the People's Republic of China (1989).

34 Chen (n 31) 428.

35 ibid 430 . 
industry, able to function and extract mineral resources with less concern for the interest of the community where it operates. The negative societal effects of the extractive industry, which can be seen in underdevelopment, political mismanagement, and military conflict, have been linked to the experience of a "resource curse". ${ }^{36}$

In most developed economies, the effects of resource curse were minimised due to the diversification of the economy and prudent government policy. ${ }^{37}$ Even in some developing countries such as Chile, Botswana and Malaysia, good governance went a long way in making them achieve this success. ${ }^{38}$ Good governance informs the making of policies and laws that would counterbalance the resource curse and make the extractive industries in the resource rich countries amenable to the community they find themselves.

The enclave mentality of the extractive industries, especially in the developing countries, underscores a culture of a business run for the sole and exclusive benefit of the incorporators. This will defeat what Amodu perceives as "the pursuit of social efficiency" as other stakeholders, such as the local community will remain genuinely aggrieved. ${ }^{39}$ Thus, the need to balance varying interests of all constituents/stakeholder vis-à-vis the operation of extractive industries logically calls for legislative intervention. This is the basis of the Community Development Agreement (CDA) as enshrined in the Nigerian Minerals and Mines Act 2007 (NMMA, 2007), being the principal law governing the solid minerals sector of the Nigerian economy.

Section 116 of the NMMA, 2007 makes it mandatory, to the mining companies that have approved mining licence, to negotiate an agreement with the community where the mining operation is to commence. The law makes commencement of operation subject to the CDA. This requirement inevitably makes the mining industry to interact with an important stakeholder

36 Its impact on conflict in the community where it operates is far reaching. Thus the extraction of natural resources requires little human co-operation and tend to be less affected by violent conflict than manufacturing or service industries, because multinational companies can build necessary infrastructure and they are able to provide their own security; being exclave economies they rely little on local business linkages. See Jedrzej George Frynas, "Corporate Social Responsibility and Societal Governance: Lessons from Transparency in the Oil and Gas Sector" (2010) 93(2) Journal of Business Ethics, pp. 163, 164.

37 Frynas (n 36) 164.

38 ibid.

39 Social efficiency notion connotes that the corporate form needs to be employed to advance the aggregate welfare of all whose interests or stakes are genuinely affected by a company's operations and activities. See Amodu (n 21) 1255. 
who directly bears the impact of mining operations. It provides an opportunity to the concerned community to know the nature of the business to be conducted in their community and its environment, and through this, possibly conjecture the likely effects to their community character, their livelihood, culture, etc. Where there is need for further clarification, the interaction between the community and the mining company provides avenue for continued negotiation where knotty issues are clarified to the satisfaction of all parties. What better socially responsible interaction can be fostered through this legislatively obliged collaboration between the mining companies and the community where the mining is to take place! ${ }^{40}$

The CDA is expected to cover such areas as: educational scholarship, apprenticeship, technical training and employment opportunities for indigenes of the communities; ${ }^{41}$ financial or other forms of contributory support for infrastructural development and maintenance such as education, health, or other community services, roads, water and power; ${ }^{42}$ assistance with the creation, development and support to small-scale and micro enterprise; ${ }^{43}$ agricultural product marketing; ${ }^{44}$ methods and procedures of environmental and socio-economic management and local governance enhancement. These highlighted areas are designed to confer social and economic benefits on the

40 Enlightened corporations worldwide including mining industry have long been aware that it may be in their interests to address issues of concern to the local communities in which they operate. The pragmatic logic involved in this notion is that local communities are often in a position to impose costs on corporations with their ability to do so being a function of the resources they command and their ability to organise themselves. This was very well witnessed in the Niger Delta region of Nigeria where the community rebelled against the perceived injustice by the oil companies as they pollute the community's riverine environment thereby disrupting their aquatic means of livelihood. The fight against the oil corporations did not occur only through violent militant acts against the oil companies' installation but also pursued through court actions. See Paul Kapelus,"Mining, Corporate Social Responsibility and the Community: The Case of Rio Tinto, Richards Bay Minerals and the Mbonambi" (2002) 39(3) Journal of Business Ethics, pp. 275, 276; Olufemi Amao, "Corporate Social Responsibility, Multinational Corporations and the Law in Nigeria: Controlling Multinationals in Host States" (2008) 52(1) Journal of African Law, pp. 89,102; See also the case of Gbemre $v$ Shell Petroleum Development Company (Suit No. FHC/B/CS/53/05) Federal High Court, Benin Judicial Division, 14 November 2005.

41 Section 116 (3) (a) NMMA, 2007.

42 Section 116 (3)(b) NMMA, 2007.

43 Section 116 (3)(c) NMMA, 2007.

44 Section 116 (3)(d) NMMA, 2007. 
host communities from the mining company as it proceeds with its mining activities.

A distinctive effect of the CDA is that it breaks down the wall often erected by government agencies and powerful mining corporations on the one hand and the rightfully suspicious, generally uninformed and genuinely apprehensive host community on the other. ${ }^{45}$ The CDA obliges attention to be paid to the local community where mining is to take place. This is a new phenomenon in the developing world as against the fact that corporations have paid more attention to concerns of mining communities in the developed countries in which they operate than those in the developing countries. ${ }^{46}$

Section 164 of the NNMA 2007 did not give interpretative explication on what the term "community" should be. This raises the question as to how the mining industries should be able to identify the community that they should negotiate a CDA with. While the ordinary meaning of the word "community" could be used to determine the proximate human existence in the area of mining activity as they would bear the direct influence of the mining activities, what about those non-proximate human existence that do not share immediate physical community with the mining activity but also are affected by the effect of the mining activity? ${ }^{47}$ If the Act is not specific as to the identification of host community that is qualified for a CDA with the mining company then who does this? Is this left at the discretion of the mining companies?

Identifying a community is a complex and contested task, especially in contemporary societies. ${ }^{48}$ Identifying communities could be on the basis of analogous traits such as territory, religion, culture, history, kinship etc. It

45 There is the apparent non-compliance with section 116 of the NMMA 2007 by Dangote Cement which has caused anger at the Mbayion community of Benue State, Nigeria; occasioned by cases of mass termination of employment of natives, and the blasting of rocks near residential areas, causing deaths, water pollution, etc. This disconnect between the host community and the cement company would have been averted if statutory provisions have been complied with. See Asan Gabin Bennedict, "Dangote Cement and Mbayion Community: Documentation of ESCR Violation and Cement Production" Economic \& Social Right, Governance, Human Rights 8 October 2013 <lawyersalert.wordpress. com $>$ accessed 14/09/2015.

46 Kapleus (n 40) 276.

47 Take, for example, the effect of shocks and vibration of blasting limestone used by cement companies, which reverberates for many kilometres creating discomfort to the life of the community near and far away from the radius of blast.

48 Kapleus (n 40) 281. 
could also be on the basis of subterranean identity appellation which event may cause to change over time. Whatever the case, attempting to identify a community is fraught with "contestations" between those that are included in the identified community and those excluded. ${ }^{49}$ The Nigerian Minerals and Mines Regulation 2011 has made the task of identifying the host community a less herculean task by defining it as a community where the mineral is located or the community closest to it or through a combined identification by state or federal agencies in a report to the minister or wherever the minister determines it to be. ${ }^{50}$

\section{STAKEHOLDER THEORY AND THE COMIMUNITY DEVELOPMENT AGREEMENT}

A contemporary view among leading thinkers about corporate governance is that corporations exist to create wealth for the society. ${ }^{51}$ The corporation's existence is not merely to satisfy owners ${ }^{52}$ but to include and engage other players (stakeholders) who are affected by the corporation's activities. ${ }^{53}$ Donaldson and Preston have argued that in modern corporations all stakeholders have some stake or moral interest in the affairs of corporation. They conclude that "the normative principles that underlie the contemporary pluralistic theory of property rights also provide the foundation for stakeholder theory as well." ${ }^{\prime 4}$ The modern corporation has also been aptly described as a "constellation of interest" rather than the instrument of the acquisitive individual. ${ }^{55}$ This constellation of interest includes those of the shareholders and other stakeholders. The weakening of shareholder's role in managing

49 ibid.

50 See Regulation 193 (5) (a), (b), (c) of the Minerals and Mines Regulation 2011.

51 Margaret M. Blair, "Ownership and Control: Rethinking Corporate Governance for the Twenty-first Century," in Thomas Clarke (ed.) Theories of Corporate Governance (Routledge, Taylor \& Francis Group, 2004) 174-188.

52 This is the property conception of corporation.

53 This is the social conception of corporation. See Blair (n 51) 176-177.

54 See T. Donaldson and L.E. Preston, "The Stakeholder Theory of the Corporation: Concepts, Evidence, Implications" (1995) 20 Academy of Management Review 65-91. This position has been railed against by Milton Freidman who believes that "business men" who have this opinion are "unwitting puppets of the intellectual forces that have been undermining the basis of a free society..." See Milton Friedman, "The Social Responsibility of Business is to Increase its Profits" New York Times Magazine (13 September 1970), p. 33.

55 D. Votaw, Modern Corporation (Prentice-Hall, 1965) 28; See also Blair (n 51) 177; W.T. Allen, "Our Schizophrenic Conception of Business Corporation," (1992) 14 (2) Cardozo Law Review, pp. 261-281. 
business and the rise of professional management is associated with a growing recognition of the significance of the role and contribution of other stakeholder groups to the performance of the company. ${ }^{56}$

Conception on stakeholder role and objectives has a long intellectual lineage beginning with the pioneering work of Berle and Means. ${ }^{57}$ Their work identified various other interest groups within a corporation other than the owner such that "neither the claims of ownership nor those of control can stand against the paramount interest of the community..." 58 The work of Edith Penrose and others have laid down the intellectual foundation and momentum for the stakeholder theory. ${ }^{59}$ The stakeholder theory of the firm assumes, first, that a firm can be viewed as a set of interdependent relationships among primary stakeholders. Second, that the purpose of the firm is not the maximisation of shareholder's value, but the creation and distribution of value to a plurality of stakeholders. Third, the achievement of this purpose depends on the cooperation and support of the stakeholders themselves. ${ }^{60}$ In the stakeholder's view, the ultimate purpose of the firm is the combined production of economic and social welfare. ${ }^{61}$

Freeman's Stakeholder Theory holds that a firm has relationship with a broad variety of stakeholders, including government, competitors, consumers, environmental advocates, the media and others. ${ }^{62}$ The argument of the

56 Thomas Clarke, “The Stakeholder Corporation: A Business Philosophy for Information Age" in Thomas Clarke (ed.) Theories of Corporate Governance: The Philosophical Foundations of Corporate Governance (Routledge, Taylor \& Francis Group, 2004), pp. 189-201.

57 A.A. Berle and G.C. Means, The Modern Corporation and Private Property (Commerce Clearing House, 1932).

58 See Berle and Means (n 57) 312; See also Clarke (n 56) 191.

59 See Edith Penrose, The Theory and Growth of the Firm (Oxford University Press, 1959); Igor Ansoff, Corporate Strategy (Mcgraw-Hill, 1965); R.E Freeman, Strategic Management: A Stakeholder Approach (Pitman,1993); R.E. Freeman and D.L. Reed, "Stockholders and Stakeholders: A New Perspective on Corporate Governance" (1983) XXV(3), California Management Review, pp. 88-106

60 Mario Minoja, "Stakeholder Management Theory, Firm Strategy, and Ambidexterity," (2012) 109 (1), Journal of Business Ethics, pp. 67-82.; see also A.J. Hillman and G.D. Keim, "Shareholder Value, Stakeholder Management and Social Issues: What's the Bottom Line?" (2001) 22(2), Strategic Management Journal, pp. 125-139.

61 Minoja (n 60) 68.

62 See R.E Freeman, Strategic Management: A Stakeholder Approach (Pitman, 1993); See also Hoje Jo and Maretno A. Harjoto, "The Causal Effect of Corporate Governance on Corporate Social Responsibility" (2012)106 (1), Journal of Business Ethics, pp. 53-72. 
stakeholder theory is advanced by stating that attending to stakeholder framework leads today's managers to switch attention away from the financial health of their company and start measuring strategic health. ${ }^{63}$ In fact the stakeholder model has been a basis of industrial success in Europe and Asia. ${ }^{64}$ The conception is deeply rooted in Japan where a large percentage of companies agree that a firm exists for the interest of all stakeholders. ${ }^{65}$

Under the stakeholder theorising, the firm is a different entity to its stakeholder and their existence is the mutual and cooperative interaction in meeting their set target. ${ }^{66}$ Observably, a daunting task facing the theory is the "lack of specificity around stakeholder identity..." which remains a serious obstacle "to further development of the stakeholder theory and its adoption in actual practice by managers." ${ }^{\prime 7}$ Within the stakeholder theory are many streams of work that emphasise different elements of stakeholder management each of which affect stakeholder identification. Donaldson and Preston categorise these approaches on the basis of descriptive accuracy, instrumental power and normative validity. ${ }^{68}$

The mentioned categorisations are all firm-centric views of the stakeholder identity and legitimacy with primacy of economic relations to the firm and secondary classification of stakeholders who have non-economic claims. Cranes observed that there is the possibility of ignoring or not accounting for important and marginalised interests with this firm-centric view of stakeholder. He advocates for a social identity view "where societal constituents are presented not as secondary actors who play subservient role to 'primary' economic transaction-based stakeholder but as empowered and engaged

63 W. Lazonick, Controlling the Market for Corporate Control: The Historical Significance of Managerial Capitalism, Industrial and Corporate Change (Oxford University Press, 1992), p. 1.

64 Clarke (n 56), p. 198.

65 K. Yoshimori, "Whose Company is it? The Concept of Corporation in Japan and the West" (1955) 28(4) Long Range Planning 33-44 cited in Clarke (n 56) 199.

66 Andrew Crane and Trish Ruebottom, "Stakeholder Theory and Social Identity: Rethinking Stakeholder Identification" (2011) 102 (1) Journal of Business Ethics, pp. 77-87.

67 See L. Dunham, R.E. Freeman and J. Liedtka, "Enhancing Stakeholder Practice: A particularised Exportation of Community" (2006) 16 (1) Business Ethics Quarterly, pp. 23-42.

68 For a full explanation of these categories see Cranes (n 66) 78; See also T. Donaldson and L.E. Preston (n 54). 
culturally adept social actors who present to corporation a range of conflicting societal interests." ${ }^{169}$

This is where the idea of Community Development Agreement (CDA) is engaged. The firm does not operate economically in vacuo but within a defined physical environment in a community. While the community may not play the economic transaction-based role ascribed to the primary stakeholder, it is a key element in the firm's external environment that can positively or negatively affect the organisation. ${ }^{70}$ Creating social value for the community as a stakeholder is the essence of a CDA. Companies, through their corporate social responsibility, provide an avenue for companies to fulfil this mandate.

The environment where the companies operate and the nature of the economic activity often determine the level to which these companies will fulfil their CSR. In a developing country like Nigeria, the extractive industries sector is populated by enclave industries that may operate without necessarily engaging with the community. This has fuelled tension and opposition in the community where minerals are mined. ${ }^{71}$ Therefore, obligating firms operating in the minerals and mine sector of a developing country like Nigeria to carry out social responsibility in the form of a CDA allows for social peace while it supports and validates the underlying assumptions of the stakeholder theory.

To understand the dynamics between the CDA, as practised in the Nigerian reality and the CSR of major players in the country, we shall now take a look at Dangote Cement as a major player in the growing solid minerals sector of Nigeria. We shall look into the company's CSR policy vis-a vis international practices as expressed in existing literature.

\section{DANGOTE'S CSR AGENDA}

Established in May 1981 as a trading business with an initial focus on cement, the Dangote Group diversified over time into a conglomerate trading in cement, sugar, flour, salt and fish. By the early 1990s, the Group had grown into one

69 See Crane (n 66) 80 quoting J. M. Handelman, "Corporate Identity and the Societal Constituent" (2006) 34 (2) Journal of Marketing Science, pp. 107114).

70 Linda O’Riordan and Jenny Fairbrass, "Corporate Social Responsibility (CSR): Models and Theories in Stakeholder Dialogue" (2008) 83(4) Journal of Business Ethics, pp. 745-758.

71 This is in reference again to the Niger Delta crisis in Nigeria over the community indifference shown by the MOCs even as they carry out extractive activities in the Niger Delta community. 
of the largest trading conglomerates operating in the country. ${ }^{72}$ The Dangote Group is headquartered in Lagos, Nigeria, with interests across a range of sectors in Africa. The Group focuses on the provision of local, value-added products and services that meet the needs of the African population. Dangote Cement, a subsidiary of Dangote Group, is the largest cement production company in Africa, with a market capitalisation of almost US\$14 billion on the Nigeria Stock Exchange, and has subsidiaries in Benin, Cameroon, Ghana, Nigeria, South Africa and Zambia.

Dangote Cement is a fully integrated cement company, and has projects and operations in Nigeria and 14 other African countries. Dangote Cement's current total production capacity in Nigeria from its three existing cement plants namely Obajana, ${ }^{73}$ Ibese $^{74}$ and Gboko ${ }^{75}$ is 20.25MMTPA. The relationship between the cement company and its host communities (especially in Obajana and Ibese) is frosty because of the firm's neglect of its poor host communities and its supposed failure to honour an agreement with the town. ${ }^{76}$ It has become a common occurrence to see Obajana town in total darkness, having no electricity, while Dangote Cement is unable to consume all the power it generates from its $1000 \mathrm{MW}$ power station. Consequently it has reached an agreement with the federal government to send the excess to the national grid. ${ }^{77}$ The education facilities are decrepit in the community, yet the company has stopped the annual award of scholarships to the young people of Obajana. This is a gross violation of the Obajana CDA with the cement company. ${ }^{78}$

Similarly, the people of Ibese community, Yewa North Local Government Area of Ogun State, have threatened to take Dangote Cement Plc to court over the company's alleged failure to sign a CDA with the host community as required by the law before it commenced operation. ${ }^{79}$ This has dissatisfied the Ibese community immensely. ${ }^{80}$

72 Dangote: About us < www.dangote.com/aboutus/history.aspx>

73 10.25 Million Metric Tonnes Per Annum.

74 6.0 Million Metric Tonnes Per Annum.

75 4.0 Million Metric Tonnes Per Annum.

76 Dangote, in line with the law, has signed a CDA with the Obajana community but events subsequent to the agreement shows that Dangote is not living up to the side of its bargain. See Clement Obando, "Is Dangote CSR Challenged?" The Guardian Newspapers (29 June 2015).

77 See Clement Obando ( $\mathrm{n} 76)$.

78 It is also a derogation from the requirements of Section 116(3)(b) of the NNMA, 2007. See also Obando (n 76).

79 See the report of Daud Olatunji, "Community Threatens Dangote Cement Firm over MOU” The Vanguard Newspapers (3 November 2011).

80 ibid. 
Dangote Group's involvement in CSR activities necessitated the setting up of the Dangote Foundation, which oversees the implementation of this objective. The Foundation intervenes in the areas of health, education and empowerment. The Foundation is also involved in providing humanitarian aid to victims of natural disasters. The Dangote Group has resolved to touch the lives of Nigerians and the idea of the group being responsible to the society is declared to be embedded in the ethics of the group's businesses with the company always striving to take steps to improve the quality of life of its employees and their families as well as the local community. ${ }^{81}$

Looking at the mission and vision of Dangote Group, can one say it sees CSR as primarily a moral responsibility or a business strategy? Dangote's CSR policy, as outlined in its website, is scanty and not clearly defined in terms of policy thrust and philosophical outlook on CSR. What is presented is more of an outline of philanthropic or charity gestures doled out to the needy in the society. Philanthropy or charity plays a different role to CSR. While the former gives the company a feel-good image, the latter goes to the corporate ethos, and impacts on all the stakeholders of the company. ${ }^{82}$ Dangote Group has failed to move away from the stale idea of corporate philanthropy to the contemporary CSR module targeted at capacity building of stakeholders other than shareholders. They failed to heed the enlightening comments of Rajak thus:

In so doing, mining companies have moved away from the rhetoric of philanthropy towards that of capacity building...CSR, therefore, claims a radical break with the legacy of corporate philanthropy - charity replaced by the technocratic rationalism of "responsible competitiveness" and "sustainable development", while stakeholder engagement and participation take the place of the mine manager's paternalism. ${ }^{83}$

81 The Group Head Corporate Communication of the Group, Anthony Chiejina expressed this view though such is not embedded in the written CSR mandates of Dangote Group's website. See "Dangote Constructs 50m Dam for Benue Communities" < www.myfinancialintelligence.com> accessed 26 July 2015.

82 CSR acknowledges the debt that the corporation owes to the community within which it operates as a stakeholder in corporate activity. This blends with the emerging perspective of CSR, which focuses on responsibility towards stakeholder. See further Amita (n 20); Nojeem Amodu (n 21); John L. Cambell (n 30).

83 D. Rajak, "Uplift and Empower": The Market, the Gift and Corporate Social Responsibility on South Africa's Platinum Belt (2008) 28, Research in Economic Anthropology, pp. 297-324. See also Sabine Luning, "Corporate Social Responsibility (CSR) for exploration: Consultants, companies and communities in processes of engagements" (2012) 37 Resources Policy 205, 206. 
A critical look at Dangote's conception and actualisation of CSR brings one to the conclusion that it sees CSR as nothing beyond a business strategy designed to achieve its financial aim..$^{84}$

This vision is reactive in the group's attitude to social responsibilities rather than proactive. This can be observed in Dangote's lists of what it terms as social responsibility: renovation of classroom blocks; sinking of boreholes in local communities; cash disbursement to the needy; distribution of Sallah rams; distribution of relief materials to disaster victims, etc. ${ }^{85}$ Perhaps a clear indication of the attitude of Dangote Cement (as a subsidiary of Dangote group) towards CSR is its failure to sign a CDA with the Ibese community in Ogun State where it is mining limestone for the production of cement. ${ }^{86}$ The failure of Dangote Cement to negotiate a CDA with the Ibese community is clearly a violation of section 116 of the NMMA 2007. The law is clear as to the necessity of contracting a CDA with the host community, a precondition for the commencement of mining activity.

That Dangote commenced mining activities in Ogun State in clear violation of the law suggests the low esteem Dangote holds CSR to its core business pursuit. This also suggests that the government agencies created to monitor the enforcement of the Mining Act ${ }^{87}$ are weak and perhaps devoid of the capacity to take on a growing conglomerate as Dangote Group within the Nigerian business firmament. This, of course, does not speak well of the enforcement mechanism of the NMMA, 2007.

Furthermore, Dangote's influence in government can be seen through the deployment of the police and the army in the forceful quelling of the display of dissatisfaction in the Mbayion communities of Benue State of Nigeria. ${ }^{88}$ In

84 Kapelus (n 40) 279.

85 See Corporate Social Responsibility: Dangote CSR Profile <www.dangote.com/ aboutus/responsibility.aspx > accessed 26 July 2015.

86 It was after the protest of the indigenes of the host communities in 2011 and the subsequent threat of the youth to disrupt production of cement in Ibese for failure to sign a CDA with the community that Dangote Cement Plc, in Ibese, Yewa and Ewekoro in Ogun State announced the inauguration of some 19 different Corporate Social Service projects for the communities. See the report of Kayode Ogundele, "Dangote Cement Boosts CSR for Ibese Host Communities" Newsmail Newspapers (20 May 2015).

87 This is the Mines Environmental Compliance Department of the Ministry of Mines and Steel. See Regulation 193 (12), (13) Of the Nigerian Minerals and Mines Regulation 2011.

88 See the report of Ibanga Isine, "Dangote Opens Talks with Gboko Community where Soldiers Kill Seven” Premium Times Newspaper (2 July 2014). 
their usual reactive manner, Dangote Cement subsequently attempted to settle frayed nerves in the host community through cash disbursement, scholarship award and building of ad hoc social amenities to the people affected by the violence. ${ }^{89}$

The observed change in attitude of Dangote from a recalcitrant violator of extant law to a pliable entity capable of acceding to the demand of the poor in the host community where the company mines attests to the capacity for legislation to empower the weak against the strong, thereby making the strong amenable to contemporary reality which involves CRS in the corporate ethos of the mining industries world over.

\section{CONCLUSION}

By law, the community where mining is taking place is an important stakeholder to firms engaged in the solid minerals sector of the country. By practice, the CSR module does not operate as a mere corporate philanthropy, but as part of the ethos of the mining company, which takes CSR as a source of empowerment of a recognised stakeholder in the achievement of their corporate target. The NMMA, 2007, in enshrining the CDA as part of the body of laws aimed at directing mining companies within Nigeria towards a proper recognition of the community as an important stakeholder in the business of mining has extended the corporate aim of mining companies in Nigeria beyond the maximisation profit for shareholders to the creation of social to value for all stakeholders. The more the host communities become aware of this law and are willing to pursue its enforcement, the more corporate giants like Dangote Group will be compelled to redesign their corporate module of CSR to meet accepted modern practices.

89 Id. See also the comment of the Group Head Corporate Communication of Dangote Group, Anthony Chiejina where he outlined how the group has built a dam, awarded scholarship and built fourteen blocks of classroom in the host communities in Gboko Benue State: "Dangote Constructs 50m Dam for Benue Communities" <www.myfinancialintelligence.com> accessed 26 July 2015. 